\title{
PREPARE PRIMARY SCHOOL STUDENTS TO FACE THE TECHNOLOGICAL AGE: MATHEMATICAL CREATIVITY AND SPATIAL ABILITY
}

\author{
Minanur Rohman \\ Department of Mathematics, Ondokuz Mayıs University, \\ Turkey \\ minanurrohmanali@gmail.com
}

\begin{abstract}
Technology and mathematics are two things that are interconnected and influence. Technology, such as computer games, can be used to describe abstract mathematical concepts so that they are more easily understood by students. Unfortunately, technology also has some undesirable impacts, such as causing students difficulties in developing their creativity to understand mathematical concepts. On the other hand, spatial ability gets less attention than educators when students are studying mathematics. This paper will discuss how teachers can help students develop their mathematical creativity and spatial ability.
\end{abstract}

Keywords: Technology, mathematical creativity, and spatial ability.

\begin{abstract}
Abstrak
Teknologi dan matematika adalah dua hal yang saling terkait dan berpengaruh. Teknologi, seperti game komputer, dapat digunakan untuk menggambarkan konsep matematika abstrak sehingga lebih mudah dipahami oleh siswa. Sayangnya, teknologi juga memiliki beberapa dampak yang tidak diinginkan, seperti menyebabkan siswa kesulitan dalam mengembangkan kreativitas mereka untuk memahami konsep matematika. Di sisi lain, kemampuan spasial kurang mendapat perhatian dibandingkan pendidik
\end{abstract}


AL-MUDARRIS:journal of education, Vol. 2. No. 1 April 2019, ISSN: 2620-5831 (print), ISSN: 2620-4355(online)

DOI: $10.32478 /$ al-mudarris.v2i1.237

ketika siswa belajar matematika. Artikel ini akan membahas bagaimana guru dapat membantu siswa mengembangkan kreativitas matematika dan kemampuan spasial mereka.

Kata kunci: Teknologi, kreativitas matematika, dan kemampuan spasial

\section{A. INTRODUCTION}

In recent years, the development of technology has run very fast and has penetrated almost all fields. This is a challenge for teenagers who are currently following the learning process because they have to prepare themselves to the face of an era where almost everyone must be able to master in technology. Because mathematics is a lesson that is very related to technology ${ }^{1}$, the teacher must realize that they are the main factor that will prepare students' abilities.

Abstract and free mathematical properties require children to be able to think creatively. This mathematical creativity has recently come to be considered an essential skill that may and should be enhanced in all students ${ }^{2}$, and creative thinking is an important goal in primary mathematics education. ${ }^{3}$ Mathematical creativity must be developed as early as possible for students because the rapid development of technology is seen as something that raises more uncertainty than before ${ }^{4}$ and digitalization that makes

${ }^{1}$ Gravemeijer, K., Stephen, M., Julie, C., Lin, F-F., Ohtani, M. (2017). What mathematics education may prepare students for the society and student. International Journal of Science and Mathematics Education 15(1). 105-123.

${ }^{2}$ Mann, E. (2005). Mathematical Creativity and School Mathematics: Indicators of Mathematical creativity in Middle School Students. Doctoral dissertation.

${ }^{3}$ Leikin, R., \& Sriraman, B. (2017). Creativity and Giftedness. Interdisciplinary perspective from mathematics and beyond. Basel: Springer International Publishing.

${ }^{4}$ Craft, A. (2011). Creativity and education futures: Learning in digital age. England: Trentham Books. 
AL-MUDARRIS:journal of education, Vol. 2. No. 1 April 2019, ISSN: 2620-5831 (print), ISSN: 2620-4355(online)

DOI:

almost everything easy resulting in many students experiencing a crisis of creativity. ${ }^{5}$

In addition to mathematical creativity, the development of spatial ability has also escaped the attention of educators or people engaged in education. This is due to the assumption that spatial ability has no relationship and influence on mathematics learning. Newcombe ${ }^{6}$ suggested that spatial learning is integrated into the mathematics curriculum. This suggestion is not without foundation, because many studies show that spatial abilities can help students understand mathematical concepts (Jonathan, et al. 2009; Bornstein, 2011). ${ }^{7}$ In this paper, we will discuss the necessity of mathematical development, and the necessity of mathematical creativity and spatial ability while studying mathematics.

\section{B. TECHNOLOGY AND MATHEMATICS}

Technological developments experience acceleration which is directly proportional to increasing time. For example, the development of a microchip computer is not only in its smaller form, but also processing speed, memory capacity, energy efficiency, and download speed. ${ }^{8}$ As a result, automation is inevitable which can cause many people to lose their jobs. ${ }^{9}$ In addition, there is a positive

${ }^{5}$ Bronson, P. O., \& Merryman, A. (2010, July 19). The creativity crisis. Newsweek, pp. 44-50

${ }^{6}$ Newcombe, N. S. (2013). Seeing relationship: using spatial thinking to teach science, mathematics, and social science. American Educator. 37. 2631 and 40 .

7 Bornstein, M. H. (2011). The mind of preschool child: The intelligence-school interface. In O. A. Barbarin \& B. H. Wasik. (Eds.), Handbook of Child Development and Early Education: Research to Practice (pp. 123-142). New York: Guilford Press.

${ }^{8}$ Brynjolfsson, E., \& McAfee. (2014). The second machine age: Work, progress, and posperity in a time of brilliant technologies. New York, NY: WW Norton \& Company.

${ }^{9}$ Frey, C. B., \& Osborne, M. A. (2013). The future of employment: How susceptible are jobs to computerization. Retrieved on February 122019 from 
AL-MUDARRIS:journal of education, Vol. 2. No. 1 April 2019, ISSN: 2620-5831 (print), ISSN: 2620-4355(online)

DOI: $10.32478 /$ al-mudarris.v2i1.237

tendency that requires workers to have complex thinking and communication skills ${ }^{10}$ to operate the technology applied in a company. Therefore, education has a very important role in preparing students to have competencies that cannot be replaced by technology.

Technology is very closely related to mathematics because mathematics is the core that allows technology to work properly. Therefore, technological development is directly proportional to the development of mathematics, and vice versa. ${ }^{11}$ The interesting thing is that most students (even mathematics teachers) do not understand the function of actual mathematics. Almost all mathematical operations starting from elementary to advanced mathematics mostly can be handled by computers, so some people cannot distinguish mathematics from school and in everyday life (Wolfram, 2010). A teacher makes mathematical questions that will be solved by students, while a worker makes a mathematical model that will be solved by the computer. This raises the opinion of most of us that learning mathematics is not important. ${ }^{12}$

As we mentioned earlier, the teacher must deflect the goals of mathematics learning which previously focused on counting (which can be done by a computer) into an analytical understanding of concepts. It is not an easy thing to form strong mental cognitive mathematics. It is impossible for this formation to begin at the university level

http://www.oxfordmartin.ox.ac.uk/downloads/academics/The Future of Empl oyment.pdf.

${ }^{10}$ Levy, F., \& Murnane, R. J. (2012). The new division of labor: How computers are creating the next job market. Princeton, NJ: Princeton University Pers.

${ }^{11}$ Gravemeijer, K., Stephen, M., Julie, C., Lin, F-F., Ohtani, M. (2017). What mathematics education may prepare students for the society and student. International Journal of Science and Mathematics Education 15(1). 105-123.

${ }^{12}$ Keeler, S. P., \& Grandine, T. A. (2013). Getting math off the ground. In A. Damlain, J. Rodrigues \& R. Strasser (Eds). Educational interfaces between mathematics and industry. Report on an ICMI-ICAM Study. Cham, Switzerland: Springer. 
AL-MUDARRIS:journal of education, Vol. 2. No. 1 April 2019, ISSN: 2620-5831 (print), ISSN: 2620-4355(online)

DOI:

because mental cognitive is formed in a long time. Therefore, this cognitive mental formation starts at an early age, at least in primary school level.

How a teacher teaches mathematics is one thing that has a very important role in shaping students' mathematical understanding. The difference in how teachers teach depends on the teacher's opinion about effective learning 1,01 cmarithmetic operations. Level 1 (basic talent: the culture talent) is creativity that is able to carry out four basic mathematical operations to solve a basic arithmetic problem. Level 2 (the honors student) is a level of creativity that is already very good at doing algebraic processes. The students who always do their homework can attain this level. Level 3 (the terrific student) is creativity that is able to see a function or mapping as an object, not an algebraic process. Students at this level can find the answer to a function $\mathrm{f}(\mathrm{x})$ for an $\mathrm{x}$ without doing mathematical calculations. Students in this level have done all the function operations in their minds because they have previously solved a mathematical problem that is far more complicated than what was learned in class. Creativity level 4 (the exceptional students) is a level where students no longer view mathematics as a number, but rather a logical way of thinking based on the propositions given. Students at this level are students who usually take part in math olympiad. Level 5 (The productive mathematician) is the creativity possessed by a mathematician. In other words, students are not interested in learning lessons other than mathematics. Students at this level are accustomed to performing calculus operations and looking at functions or mapping as objects and then performing calculus operations on the function. Mathematical creativity Level 6 (the exceptional student) is owned by students who have been able to apply advanced mathematical concepts and discover new things. In other words, students with level 6 math creativity are students who can solve real problems (such as finding locations containing petroleum using mathematics). Level 7 (the exceptional student) is the level of creativity 
AL-MUDARRIS:journal of education, Vol. 2. No. 1 April 2019, ISSN: 2620-5831 (print), ISSN: 2620-4355(online)

DOI: $10.32478 /$ al-mudarris.v2i1.237

possessed by students who understand advanced mathematical concepts without learning them. Students who have level 7 math creativity do not need a teacher in learning mathematics, because their way of thinking is very abstract and outside the normal way of thinking. One of the people in this level is Srinivasa Ramanujan who says that $1+2+3+\cdots \cdot=\frac{-1}{12}$

How can an infinite addition of a positive integer produce a "negative fraction" number?

Beghetto and Kaufman ${ }^{13}$ offer a C-model of creativity that consists of four levels. The basic levels of mini-creativity are self-discoveries, new and meaningful insights and interpretations that are a component in the learning process. Simply put, mini-C is an intuition that arises from previous students' knowledge or experience. When given feedback on this creative mini-C, it will be little-C creativity which is defined as the creativity that is in everyday life. When students often practice, little-C will develop into pro-creativity which is owned by students who are already proficient in a mathematical concept. With the passage of time and increasing knowledge, pro-C will develop into a Big-C where students can combine several concepts at once to understand a new mathematical concept. The development of creativity in $\mathrm{C}$-models does not have to be linear, because mini-C can directly become pro-C.

The teacher has an important role in the development of creativity for primary school students. The development of this creativity will be greatly helped when teachers can form a pleasant learning environment ${ }^{14}$ and give freedom to students to construct their own

${ }^{13}$ Beghetto, R, A., \& Kaufman, J. C. (2014). Classroom context for creativity. High Ability Studies, 25(1). 53-69.

${ }^{14}$ Bolden, D. S., Harries, T. V., \& Newton, D. P. (2010). Pre-service teachers' conception of creativity in mathematics. Educational Studies in Mathematics. 73. 143-157. 
AL-MUDARRIS:journal of education, Vol. 2. No. 1 April 2019, ISSN: 2620-5831 (print), ISSN: 2620-4355(online)

DOI:

mathematical concepts. ${ }^{15}$ Unusualness and element of creativity have been strongly supported by the use of nonroutine problems, non-standard problems that are involved in unexpected and unfamiliar solutions. ${ }^{16}$

Problem-solving and motivation are the core in forming creativity. A study shows that the more creative problems and more required thinking will reduce the number of questions that can be answered correctly. However, students who managed to answer correctly gain a high sense of competence, satisfaction, and motivation (Judge, \& Gazit, 2011). Saied Bishara $^{17}$ provides a recommendation that the method of learning mathematics that is good in primary school is self-regulated because it can provoke students to use various strategies to solve problems that will develop creative thinking. Next, the teacher checks the answers using a common mathematical procedure to assess the strategies students use according to logical and creative thinking. Students' mathematical creativity will only appear if the teacher opens a longer dialogue and makes connections between mathematics and other subjects. An open atmosphere will be created if students are given the freedom to express their own ideas and teachers are open to the students' ideas. ${ }^{18}$

\section{SPATIAL ABILITY AND MATHEMATICS}

${ }^{15}$ Desli, D., \& Zioga, M. (2015). Looking for creativity in primary school mathematical tasks. Ninth Congress of the European Society for Research in Mathematics Education. Prague, Czech Republic.

${ }^{16}$ Yeo, K. K. (2009). Secondary 2 students' difficulties in solving nonroutine problems. International Journal for Mathematics Teaching and Learning. 10. 1-30.

${ }^{17}$ Bishara, S. (2016). Creativity in unique problem-solving in mathematics and its influence on motivation for learning. Cogent Education. 3. $1-14$.

${ }^{18}$ Schoevers, E. M., Lesemen, P. P. M., Slot, E. M., Bakker, A., Keijzer, R., \& Kroesbergen, E. H. (2019). Promoting pupils' creativity thinking in primary school mathematics: A case study. Thinking Skills and Creativity. 31. 323-334. 
AL-MUDARRIS:journal of education, Vol. 2. No. 1 April 2019, ISSN: 2620-5831 (print), ISSN: 2620-4355(online)

DOI: $10.32478 /$ al-mudarris.v2i1.237

Spatial ability defined as the skill in representing, transforming, generating, and recalling symbolic, nonlinguistic information. ${ }^{19}$ It is the ability to perceive and understand spatial relationship, to visualize spatial stimuli such as objects, and to manipulate or transform them in some way to imagine what it might look like viewed from different angle and perspective. In brief, such capability is the ability to imagine spatial movements of objects and shapes $^{20}$, including the objects that are manipulated visually or in the mind, whether they are folded, synthesized, or in rotation or transposition.

Linn and Petersen ${ }^{21}$ made three categories for spatial ability. Firstly, is spatial perception which involves perceiving spatial relationship. More simple, spatial perception is the ability of individuals to make comparisons, equations, or inequalities of several objects. For example, given four pictures of cubes whose size is the same as the different slope positions and one of the cubes is filled with water. The individual's spatial perception is to estimate the position of water from the first cube if the water is poured into three other cubes. The rate of growth in spatial perception can be used to predict arithmetic abilities for preschool children. $^{22}$

The second category is mental rotation that involves requiring the individual to mentally rotate. Mental rotation tasks usually involve three-dimensional stimuli. ${ }^{23}$ Presented

${ }^{19}$ Linn, M. C., \& Petersen, A. C. (1985). Emergence and characterization of sex differences in spatial ability: A meta-analysis. Child Development. 56(6). 1479-1498.

${ }^{20}$ Hegarty, M., \& Waller, D. (2004). A dissociation between mental rotation and perspective-taking spatial abilities. Intelligence. 32. 24-34.

${ }^{21}$ Linn, M. C., \& Petersen, A. C. (1985). Emergence and characterization of sex differences in spatial ability: A meta-analysis. Child Development. 56(6). 1479-1498.

${ }^{22}$ Zhang, X., \& Lin, D. (2017). Does growth rate in spatial ability matter in predicting early arithmetic competence?. Learning and Instruction, 49. 232-241.

${ }^{23}$ Kimura, D. (2000). Sex and Cognition. Cambridge, MA: MIT Press. 
AL-MUDARRIS:journal of education, Vol. 2. No. 1 April 2019, ISSN: 2620-5831 (print), ISSN: 2620-4355(online)

DOI:

four three dimensional images. Mental rotation is the ability of an individual to know which image is actually the same.

The last category is spatial visualization which involves more complicated multi manipulation of spatial information in order to reach a solution. The difference in spatial visualization with the two previous categories lies in the number of steps needed. Such as presented by 4 circle images in which in each circle have a pattern image that is not the same. Individual spatial visualization is to guess the correct loop order. Although geometry is included in mathematics lessons but is this spatial ability closely related to mathematics in general?

Spatial ability has an important role in the development of students' mathematical abilities. ${ }^{24}$ The most common theoretical perspective is mathematical thinking is supported by spatial representations. ${ }^{25}$ This ability as a higher order mental process has been considered a fundamental cognitive ability to increase efficiency in thinking of the learner to visually represent and determine the solution for problem-solving tasks. ${ }^{26}$ This happens because when students do spatial ability training, students indirectly train their effectiveness, durability, and transferability. ${ }^{27}$ These three factors are important elements that students must have when they are studying mathematics. Students who use spatial imagery and diagrams can understand mathematical concepts better

${ }^{24}$ Bornstein, M. H. (2011). The mind of preschool child: The intelligence-school interface. In O. A. Barbarin \& B. H. Wasik. (Eds.), Handbook of Child Development and Early Education: Research to Practice (pp. 123-142). New York: Guilford Press

${ }^{25}$ Mix, K. S., \& Cheng, Y. -L. (2012). The relation between space and math. In J. B. Benson (Ed.), Advances in Child Development and Behavior (42) (pp.197-243). New York: Elsevier.

${ }^{26}$ Sung, E. (2017). The influence of visualization tendency on problem-solving ability and learning achievement of primary school students in South Korea. Thinking Skills and Creativity. 26. 168-175.

${ }^{27}$ Uttal, D. H., Meadow., N. G., Tipton, E., Hand, L. L., Alden, A. R., Warren, C., \& Newcombe, N. S. (2013). The malleability of spatial skills: a meta-analysis of training students. Psychology Bulettin. 139(2). 352-402. 
AL-MUDARRIS:journal of education, Vol. 2. No. 1 April 2019, ISSN: 2620-5831 (print), ISSN: 2620-4355(online)

DOI: $10.32478 /$ al-mudarris.v2i1.237

when compared to students who only use verbal sentences ${ }^{28}$ because students with good spatial ability can map mathematical concepts effectively.

Working memory process and retain ability is a limited amount of information. There are three components in this working memory, namely the phonological loop that processes verbal information and the visuospatial sketchpad which functions to regulate visuospatial. While the third component is the central executive which functions to regulate attention. ${ }^{29}$ Visuospatial working memory and mathematics have relationships that are not constant for each individual age. This relationship is very very strong in young children and tends to decrease when it has grown up. ${ }^{30}$ The thought of children who are still in elementary school age is still relatively undeveloped and it is difficult to understand mathematical concepts that require abstraction. In four operations of basic arithmetic, addition and subtraction of elementary school students will use and develop the visuospatial abilities they have. While the operation of multiplication and division, primary school students use more verbal procedures. ${ }^{31}$ Therefore, young children will be able to understand mathematical concepts when there are visuospatial representations or visuospatial

${ }^{28}$ Spelke, E. S. (2005). Sex differences in intrinsic aptitude for mathematics and science: a critical review. American Psychologist. 60(9). 950958.

${ }^{29}$ Ven, S. H. G. van der., Maas, H. L. J. van der., Straatmeier, M., Jansen, B. R. J. (2013). Visuospatial working memory and mathematical ability at different ages throughout primary school. Learning and Individual Differences. 27. 182-192.

${ }^{30}$ De Smedt, B., Janssen, R., Bouwens, K., Verschaffel, L., Boets B., \& Ghesquiere, P. (2009). Working memory and individual differences in mathematical achievement: A longitudinal study from first grade to second grade. Journal of Experimental Child Psychology. 103. 186-201

${ }^{31}$ Ven, S. H. G. van der., Maas, H. L. J. van der., Straatmeier, M., Jansen, B. R. J. (2013). Visuospatial working memory and mathematical ability at different ages throughout primary school. Learning and Individual Differences. 27. 182-192. 
AL-MUDARRIS:journal of education, Vol. 2. No. 1 April 2019, ISSN: 2620-5831 (print), ISSN: 2620-4355(online)

DOI:

strategies $^{32}$, such as using image representations that are familiar with children (e.g. apples) to help them understand the concept of addition. With the passage of time and the increase in the knowledge they have gained, visuospatial will be replaced by verbal routines that are abstract. ${ }^{33}$

Even so, it does not mean that individuals who are adults do not need visuospatial at all. The focus is on the depth and abstractness of the mathematical concepts that are being studied. Children of age and even adults mainly rely on visually working memory when faced with problems that are new and challenging for them, while later on, they can develop verbal procedures to solve the same problems. ${ }^{34}$ When this process continues, then the individual's spatial ability will automatically develop by itself.

Spatial ability is not immutable skills, and those event-specific brief interventions can deliver improvement. ${ }^{35}$ In other words, students' spatial abilities can be improved by doing a lot of exercises which will then help students to learn math concepts more easily. The most appropriate time in developing spatial abilities along with mathematics ability is in the age range of $8-10$ years $^{36}$, which is nothing but primary school students.

${ }^{32}$ Rasmussen, C., \& Bisanz, J. (2005). Representation and working memory in early arithmetic. Journal of Experimental Child Psychology. 91. 137-157.

${ }^{33}$ De Smedt, B., Janssen, R., Bouwens, K., Verschaffel, L., Boets B., \& Ghesquiere, P. (2009). Working memory and individual differences in mathematical achievement: A longitudinal study from first grade to second grade. Journal of Experimental Child Psychology. 103. 186-201

${ }^{34}$ Raghubar, K. P., Barnes, M. A., Hecht, S. A. (2010). Working memory and mathematics: A review of developmental, individual differences, and cognitive approaches. Learning and Individual Differences. 20. 110-122

${ }^{35}$ Reilly, D., Neumann, D. L., \& Andrews, G. (2017). Gender differences in spatial ability: implications for STEM education and approaches to reducing the gap for parents and educators. In M. S. Khine (Eds.). Visualspatial Ability in STEM Education (pp. 195-224). Southporth: Springer International Publishing

${ }^{36}$ Moe, A. (2018). Mental rotation and mathematics: Genderstereotype beliefs and relationships in primary school children. Learning and Individual Differences. 61. 172-180 
AL-MUDARRIS:journal of education, Vol. 2. No. 1 April 2019, ISSN: 2620-5831 (print), ISSN: 2620-4355(online)

DOI: $10.32478 / a l-m u d a r r i s . v 2 i 1.237$

There are many ways to develop spatial ability. If students are allowed to play a game to learn a concept, this will result in definite and effective improvement in the quality of education. ${ }^{37}$ When learning and transformation material is in the form of games, this will increasingly attract students' attention and increase their learning motivation. ${ }^{38}$ Several studies show that puzzle games have a positive effect in the development of spatial abilities ${ }^{39}$, and theory-based design of multimedia games offers an effective learning environment for improving cognitive knowledge. $^{40}$

\section{REFERENCES}

Beghetto, R, A., \& Kaufman, J. C. (2014). Classroom context for creativity. High Ability Studies, 25(1). 53-69.

Bishara, S. (2016). Creativity in unique problem-solving in mathematics and its influence on motivation for learning. Cogent Education. 3. 1-14.

Bolden, D. S., Harries, T. V., \& Newton, D. P. (2010). Preservice teachers' conception of creativity in mathematics. Educational Studies in Mathematics. 73. 143-157.

Bornstein, M. H. (2011). The mind of preschool child: The intelligence-school interface. In O. A. Barbarin \& B. H. Wasik. (Eds.), Handbook of Child

${ }^{37}$ Papastergiou, M. (2009). Exploring the potential of computer and video games for health and physical education: a literature review. Computers and Education. 43(3). 603-622

${ }^{38}$ Lin, C. H., \& Liu, E. Z. F. (2009). A comparison between drillbased and game-based typing software. In Transactions on Education III, Lecture Notes in Computer Science (vol. 5940, pp. 48-58)

${ }^{39}$ Sung, Y. T., Chang, K. E., \& Lee, M. D. (2008). Designing multimedia games for young children's taxonomic concept development. Computer and Education. 50. 1037-1051.

${ }^{40}$ Lin, C. H., \& Chen, C. M. (2016). Developing spatial visualization and mental rotation with a digital puzzle game at primary school level. Computers in Human Behavior. 57. 23-30. 
AL-MUDARRIS:journal of education, Vol. 2. No. 1 April 2019, ISSN: 2620-5831 (print), ISSN: 2620-4355(online)

DOI:

Development and Early Education: Research to Practice (pp. 123-142). New York: Guilford Press. Bronson, P. O., \& Merryman, A. (2010, July 19). The creativity crisis. Newsweek, pp. 44-50.

Brynjolfsson, E., \& McAfee. (2014). The second machine age: Work, progress, and posperity in a time of brilliant technologies. New York, NY: WW Norton \& Company.

Craft, A. (2011). Creativity and education futures: Learning in digital age. England: Trentham Books.

Desli, D., \& Zioga, M. (2015). Looking for creativity in primary school mathematical tasks. Ninth Congress of the European Society for Research in Mathematics Education. Prague, Czech Republic.

De Smedt, B., Janssen, R., Bouwens, K., Verschaffel, L., Boets B., \& Ghesquiere, P. (2009). Working memory and individual differences in mathematical achievement: A longitudinal study from first grade to second grade. Journal of Experimental Child Psychology. 103. 186-201.

Frey, C. B., \& Osborne, M. A. (2013). The future of employment: How susceptible are jobs to computerization. Retrieved on February 122019 from

http://www.oxfordmartin.ox.ac.uk/downloads/acad emics/The_Future_of_Employment.pdf.

Gravemeijer, K., Stephen, M., Julie, C., Lin, F-F., Ohtani, M. (2017). What mathematics education may prepare students for the society and student. International Journal of Science and Mathematics Education 15(1). 105-123.

Guilford, J. P. (1950). Creativity. American Psychologist. 5. 444-454.

Hakim, G., \& Gazit, E. (2011). The role of creativity in solving unique problems in series with studentsSeventh compared mathematics teachers in elementary school, and students teachers to other 
AL-MUDARRIS:journal of education, Vol. 2. No. 1 April 2019, ISSN: 2620-5831 (print), ISSN: 2620-4355(online)

DOI: $10.32478 /$ al-mudarris.v2i1.237

fields of knowledge. Strong Number 2000. 20. 4048.

Haavold, P. O. (2013). What are the characteristic of mathematical creativity? An empirical and theoretical investigation of mathematical creativity (Doctoral dissertation). Retrieved from http://munin.uit.no.

Hegarty, M., \& Waller, D. (2004). A dissociation between mental rotation and perspective-taking spatial abilities. Intelligence. 32. 24-34.

Kajander, A. (1990). Measuring mathematical aptitude in exploratory computer environments. Roeper Review. 25(4). 62-65.

Kattou, M., Kontoyianni, K., Pitta-Pantazi, D., \& Christou, C. (2013). Connecting mathematical creativity to mathematical ability. ZDM Mathematics Education. 45. 167-181.

Keeler, S. P., \& Grandine, T. A. (2013). Getting math off the ground. In A. Damlain, J. Rodrigues \& R. Strasser (Eds). Educational interfaces between mathematics and industry. Report on an ICMIICAM Study. Cham, Switzerland: Springer.

Kimura, D. (2000). Sex and Cognition. Cambridge, MA: MIT Press.

Leikin, R., \& Sriraman, B. (2017). Creativity and Giftedness. Interdisciplinary perspective from mathematics and beyond. Basel: Springer International Publishing.

Levy, F., \& Murnane, R. J. (2012). The new division of labor: How computers are creating the next job market. Princeton, NJ: Princeton University Pers.

Lin, C. H., \& Chen, C. M. (2016). Developing spatial visualization and mental rotation with a digital puzzle game at primary school level. Computers in Human Behavior. 57. 23-30.

Lin, C. H., \& Liu, E. Z. F. (2009). A comparison between drill-based and game-based typing software. In 
AL-MUDARRIS:journal of education, Vol. 2. No. 1 April 2019, ISSN: 2620-5831 (print), ISSN: 2620-4355(online)

DOI:

Transactions on Education III, Lecture Notes in Computer Science (vol. 5940, pp. 48-58)

Linn, M. C., \& Petersen, A. C. (1985). Emergence and characterization of sex differences in spatial ability: A meta-analysis. Child Development. 56(6). 1479-1498.

Mann, E. (2005). Mathematical Creativity and School Mathematics: Indicators of Mathematical creativity in Middle School Students. Doctoral dissertation.

Mix, K. S., \& Cheng, Y. -L. (2012). The relation between space and math. In J. B. Benson (Ed.), Advances in Child Development and Behavior (42) (pp.197243). New York: Elsevier.

Moe, A. (2018). Mental rotation and mathematics: Genderstereotype beliefs and relationships in primary school children. Learning and Individual Differences. 61. 172-180.

Newcombe, N. S. (2013). Seeing relationship: using spatial thinking to teach science, mathematics, and social science. American Educator. 37. 26-31 and 40.

Papastergiou, M. (2009). Exploring the potential of computer and video games for health and physical education: a literature review. Computers and Education. 43(3). 603-622.

Plucker, J. \& Baghetto, R. A. (2004). Why creativity is domain general, why it looks domain specific, and why the distinction does not matter. In R. J. Stenberg, E. L. Grigorenko, \& J. L. Singer. (Eds.), Creativity from potential to realization (pp. 153168). Washington, DC: American psychological association.

Raghubar, K. P., Barnes, M. A., Hecht, S. A. (2010). Working memory and mathematics: A review of developmental, individual differences, and cognitive approaches. Learning and Individual Differences. 20. 110-122. 
Rasmussen, C., \& Bisanz, J. (2005). Representation and working memory in early arithmetic. Journal of Experimental Child Psychology. 91. 137-157.

Reilly, D., Neumann, D. L., \& Andrews, G. (2017). Gender differences in spatial ability: implications for STEM education and approaches to reducing the gap for parents and educators. In M. S. Khine (Eds.). Visual-spatial Ability in STEM Education (pp. 195-224). Southporth: Springer International Publishing.

Runco, M. A., \& Jaeger, G. J. (2012). The standard definition of creativity. Creativity Research Journal. 24(1). 92-96.

Schoevers,. E. M., Kattou, M., \& Kroesbergen, E. H. (2018). Mathematical creativity: A combination of domain-general creative and domain-specific mathematical skills. Journal of Creative Behavior. $O(0) .1-11$.

Schoevers, E. M., Lesemen, P. P. M., Slot, E. M., Bakker, A., Keijzer, R., \& Kroesbergen, E. H. (2019). Promoting pupils' creativity thinking in primary school mathematics: A case study. Thinking Skills and Creativity. 31. 323-334.

Simonton, D. K. (2012). Taking the US patent office criteria seriously: A quantitative three-criterion creativity definition and its implication. Creativity Research Journal. 24. 97-106.

Siraraman, B. (2005). Are giftedness and creativity synonyms in mathematics? The Journal of Secondary Gifted Education, 17, 20-36.

Spelke, E. S. (2005). Sex differences in intrinsic aptitude for mathematics and science: a critical review. American Psychologist. 60(9). 950-958.

Sung, E. (2017). The influence of visualization tendency on problem-solving ability and learning achievement of primary school students in South Korea. Thinking Skills and Creativity. 26. 168-175. 
DOI:

Sung, Y. T., Chang, K. E., \& Lee, M. D. (2008). Designing multimedia games for young children's taxonomic concept development. Computer and Education. 50. 1037-1051.

Usiskin, Z. (2000). The development into mathematical talented. The Journal of Secondary Gifted Education. 11(3). 152-162.

Uttal, D. H., Meadow., N. G., Tipton, E., Hand, L. L., Alden, A. R., Warren, C., \& Newcombe, N. S. (2013). The malleability of spatial skills: a metaanalysis of training students. Psychology Bulettin. 139(2). 352-402.

Veldhuis, M. \& Zhao, X. (2018). The effectiveness of mathematics teaching in primary schools. Research in Mathematics Education, 20(2), 200-204.

Ven, S. H. G. van der., Maas, H. L. J. van der., Straatmeier, M., Jansen, B. R. J. (2013). Visuospatial working memory and mathematical ability at different ages throughout primary school. Learning and Individual Differences. 27. 182-192.

Wai, J., Lubinski, D., \& Benbow, C. (2009). Spatial ability for STEM domains: aligning over 50 years of cumulative psychological knowledge solidifies its importance. Journal of Educational Psychology. 101(4). 817-835.

Yeo, K. K. (2009). Secondary 2 students' difficulties in solving non-routine problems. International Journal for Mathematics Teaching and Learning. 10. 1-30.

Zhang, X., \& Lin, D. (2017). Does growth rate in spatial ability matter in predicting early arithmetic competence?. Learning and Instruction, 49. 232241. 